\title{
Pengaruh Insentif dan Disiplin Kerja terhadap Kinerja Pegawai pada Kecamatan Citangkil Kota Cilegon
}

\author{
Achmad Rozi \\ STIE Al Khairiyah Cilegon \\ Jl. K.H. Ahmad Dahlan No.15, Citangkil, Kec. Citangkil, Kota Cilegon, Banten \\ achmad.rozi@stie-alkhairiyah.ac.id
}

\begin{abstract}
Abstrak- Penelitian ini bertujuan untuk mengetahui pengaruh insentif terhadap kinerja pegawai, untuk mengetahui pengaruh disiplin kerja terhadap kinerja pegawai dan untuk mengetahui pengaruh insentif dan disiplin kerja secara bersama-sama terhadap kinerja pegawai pada Kecamatan Citangkil Kota Cilegon Metode dalam penelitian ini menggunakan metode penelitian kuantitatif, dapat diartikan sebagai metode penelitian yang berlandaskan pada filsafat positivisme, digunakan untuk meneliti pada populasi atau sampel tertentu, teknik pengumpulan data menggunakan instrumen penelitian, analisis data bersifat kuantitatif/statistik dengan tujuan untuk menguji hipotesis yang telah ditetapkan. Populasi dalam penelitian ini adalah pegawai Kecamatan Citangkil Kota Cilegon jumlah pegawai yang dijadikan objek penelitian pada Pegawai Negeri Sipil (PNS) sebanyak 67 orang dan pegawai Non PNS sebanyak 35 orang. Jumlah populasi dalam penelitian ini sebanyak 102 orang / pegawai, dalam penelitian ini bntuk menentukan jumlah minimal sampel menggunakan rumus Slovin, Berdasarkan hasil perhitungan tersebut dengan pembulatan maka sampel ditetapkan sebanyak 31 responden. Skala pengukuran pada setiap butir kuesioner maka diperoleh penilaian terhadap butir kuesioner variabel Disiplin diperoleh rata-rata 107,00 pada kategori sangat baik dan pada variabel Disiplin Kerja diperoleh rata-rata 106,89 pada kategori sangat baik sedangkan pada variabel kinerja pegawai diperoleh rata-rata 109,00 dengan skala pengukuran pada kelas interval 105 - 124 pada kategori sangat baik. Hasil dari penelitian ini pada hipotesis satu adalah terdapat pengaruh insentif terhadap kinerja pegawai pada Kecamatan Citangkil Kota Cilegon dengan nilai korelasi sebesar 0,400 artinya nilai insentif semakin meningkat maka kinerja akan semakin meningkat. Hipotesis dua terdapat pengaruh disiplin kerja terhadap kinerja pegawai pada Kecamatan Citangkil Kota Cilegon dengan nilai korelasi sebesar 0,431 artinya nilai disiplin kerja semakin meningkat maka disiplin kerja akan semakin meningkat. Hipotesis tiga terdapat pengaruh disiplin dan disiplin kerja secara simultan terhadap kinerja pegawai pada Kecamatan Citangkil Kota Cilegon
\end{abstract}

Kata Kunci- Insentif, Disiplin Kerja dan Kinerja Pegawai

Abstract-The present study is aimed at examining the influence of incentives and work disciplines on employee performance both partially and simultaneously in Cilegon, Indonesia. 31 of 102 Citangkil district officials were selected as sample respondents using Slovin's formula. Based on the measurement scale on each item questionnaire, that the respondents were very disciplined and had good performance. The results of hypothesis testing show that incentives and work disciplines had influene on employee performance both partially and simultaneously. It can be concluded that the better the incentives, the better employee performance and that more disciplined the employees, the better their performance.

Keyword: incentives, work discipline, employee performance

\section{PENDAHULUAN}

Mewujudkan tujuan pembangunan nasional yang diamanatkan dalam UUD 1945, yaitu masyarakat adil dan makmur. Pemerintah melaksanakan pembangunan diseluruh wilayah Indonesia secara berkesinambungan untuk menciptakan masyarakat indonesia yang adil dan makmur. Untuk mencapai tujuan pembangunan Nasional tersebut diperlukan aparatur pemerintah yang mampu melaksanakan tugas pemerintahan dan pembangunan.

Sumber daya manusia memegang peranan yang sangat penting dalam mewujudkan organisasi yang ideal, karena bagaimanapun juga manusialah yang akhirnya menentukan dan memprediksikan keberhasilah atau kegagalan suatu kebijakan, strategi, maupun kegiatan langkah-langkah kegiatan yang akan dilaksanakan dalam suatu organisasi. Oleh karena itu, peningkatan kinerja sumber daya manusia (SDM) merupakan hal yang sangat penting di dalam usaha memperbaiki pelayanan kepada masyarakat, sehingga perlu diupayakan secara terus menerus dan berkesinambungan dalam menghadapi tuntutan masyarakat. Untuk menentukan hal ini perlu dicari faktor-faktor yang mempengaruhi kinerja tersebut. Sumber daya manusia memegang peranan penting yang sangat penting dalam mewujudkan organisasi yang ideal, dan perlu mendapatkan perhatian dan pengkajian yang lebih dalam.

Permasalahan birokrasi terletak pada orang utamanya yaitu pegawai Negeri Sipil sebagai pelayan 
publik dan masyarakat merupakan pelanggan yang harus dilayani secara maksimal dan professional. Olehnya Aparat pemerintah dituntut untuk meningkatkan kinerjanya sesuai dengan tugas dan fungsinya, karena kegiatan organisasi merupakan salah satu aspek yang sangat penting dalam pelaksanaan pembangunan. Dalam kegiatan organisasi kualitas sumber daya manusia sangat menentukan berhasil tidaknya program-program pembangunan yang dilaksanakan, karena sumber daya manusia merupakan motor penggerak dan pelaksana dari kegiatan organisasi. Manusia dalam sebuah organisasi adalah sosok yang harus mendapat perhatian, karena perhatian yang diberikan oleh organisasi kepadanya akan menciptakan kinerja yang tinggi dan diharapkan akan lebih termotivasi dalam pelaksanaan tugas untuk mencapai tujuan organisasi yang telah ditetapkan. Kinerja ditunjukkan dengan adanya prestasi kerja atau suatu sikap gairah dan keinginan yang terus menerus atas kesediaan untuk mengejar tujuan kelompok atau organisasi.

Kinerja birokrasi saat ini menjadi isu yang sangat strategis karena memiliki dampak yang luas dalam hal ekonomi maupun politik. Dalam hal ekonomi, perbaikan kinerja birokrasi akan dapat memperbaiki kondisi keuangan yang sangat dibutuhkan oleh Bangsa Indonesia agar bisa keluar dari krisis ekonomi yang berkepanjangan, sedangkan dalam hal politik perbaikan kinerja birokrasi pelayanan akan memiliki dampak luas terutama dalam tingkat kepercayaan masyarakat terhadap pemerintah.

Pegawai Negeri Sipil (PNS) sering mendapat sorotan terhadap kinerjanya, dikarenakan image yang tercipta dari PNS terlanjur buruk, seperti kurang produktif, suka korupsi dan menghamburkan uang negara, rendahnya etos kerja, sering bolos, dan sebagainya. Tingkat kinerja pegawai masih dibilang rendah karena kebanyakan dari mereka hanya datang, mengisi absen, ngobrol, lalu pulang tanpa memberikan jasa mereka dalam pekerjaan yang dapat mewujudkan tujuan bersama suatu organisasi pemerintah. Melihat berbagai permasalahan yang timbul, maka dibuatlah Undang-Undang baru No.5 Tahun 2014 khusus tentang Aparatur Sipil Negara (ASN) yang melingkupi standar perekrutan yang berbasis merit sistem (penilaian kinerja aparatur berdasarkan prestasi kerja), peraturan kerja pegawai aparatur negara, hingga sanksi yang diberlakukan jika tidak mentaati Undang-Undang tersebut.

Berdasarkan pada uraian tersebut diatas, maka dapat diajukan sebuah penelitian skripsi dengan: "Pengaruh Insentif Dan Disiplin Kerja Terhadap
Kinerja Pegawai Pada Kecamatan Citangkil Kota Cilegon".

\section{Pengertian Insentif}

\section{KAJIAN PUSTAKA}

Insentif merupakan salah satu jenis penghargaan yang dikaitkan dengan penilaian kinerja pegawai. Semakin tinggi kinerja pegawai, semakin besar pula insentif yang diberikan oleh perusahaan.

Menurut Rivai dan Sagala (2013 : 767) insentif diartikan sebagai bentuk pembayaran yang dikaitkan dengan kinerja dan gainsharing (pembagian perolehan), sebagai pembagian keuntungan bagi pegawai akibat peningkatan produktivitas atau penghematan biaya.

Menurut Sarwoto (2011:144) secara garis besar dimensi insentif adalah:

a. Bonus, Uang yang dibayarkan sebagai balas jasa atas hasil pekerjaan yang telah dilaksanakan.

b. Komisi, Merupakan sejenis komisi yang dibayarkan kepada pihak pekerjaan luar daerah

c. Profit Sharing, salah satu jenis insentif yang tertua. Dalam hal pembayarannya dapat diikuti bersama-sama pula, tetapi biasanya mencakup pembayaran yang disetorkan ke dalam setiap peserta/pegawai.

d. Jaminan sosial, Insentif yang diberikan dalam bentuk jaminan sosial lazimnya diberikan secara kolektif, tidak ada unsur kompetitif dan setiap pegawai dapat memperolehnya secara rata-rata dan otomatis. Bentuk jaminan sosial berupa : (a) Pemberian rumah dinas. (b) Pengobatan secara cuma-cuma. (c) Kemungkinan untuk pembayaran secara angsuran oleh pekerja atas barang-barang yang dibelinya dari Koperasi organisasi. (d) Cuti sakit. (e) Biaya pindah.

Pengertian Disiplin Kerja

Menurut Sutrisno (2013 : 86) disiplin adalah sikap kesediaan dan kerelaan seseorang untuk mematuhi dan mentaati norma-norma peraturan yang berlaku disekitarnya. Disiplin pegawai yang baik akan mempercepat pencapaian tujuan instansi, sedangkan disiplin yang merosot akan menjadi penghalang dan memperlambat pencapaian tujuan instansi tersebut.

Menurut Hasibuan (2013 : 194) disiplin pegawai dalam rangka meningkatkan produktivitas kerja pegawai dalam suatu organisasi.

Pengertian Kinerja Pegawai 
Menurut Rivai \& Sagala (2013 : 604) kinerja adalah suatu tampilan keadaan secara utuh atas perusahaan selama periode waktu tertentu, merupakan hasil atau prestasi yang dipengaruhi oleh kegiatan operasional perusahaan dalam memanfaatkan sumber-sumber daya yang dimiliki.

Menurut Mangkunegara (2011 : 67) indikator yang mempengaruhi pencapaian kinerja adalah faktor kemampuan (ability) dan faktor motivasi (motivation). yang dirumuskan bahwa :

a. Human Performance $=$ Ability + Motivation

b. Motivation $=$ Attitude + Situation

c. Ability $=$ Knowledge + Skill

Penjelasan :

a. Faktor Kemampuan

Secara psikologis, kemampuan (Ability) pegawai terdiri dari kemampuan reality (knowledge + Skill) artinya, pegawai potensi (IQ $110+120$ ) dengan pendidikan yang memadai untuk jabatannya dan terampil dalam mengerjakan pekerjaan sehari-hari, maka ia akan lebih mudah mencapai kinerja yang diharapkan. Oleh karena itu perlu ditempatkan pada pekerjaan yang sesuai dengan pekerjaannya. (the right man in the right place. The right man on the right job).

b. Faktor Motivasi

Motivasi terbentuk dari sikap (attitude) seorang pegawai dalam menghadapi situasi (situation) kerja. Motivasi merupakan kondisi yang menggerakan diri pegawai yang terarah untuk mencapai tujuan organisasi (tujuan kerja).

Kerangka Pemikiran

Insentif mempunyai hubungan dengan kinerja yang dihasilkan setiap individu, karena setiap pekerjaan pegawai yang telah memberikan kinerja terbaiknya pasti mengharapkan imbalan di samping gaji atau upah sebagai tambahan berupa insentif atas prestasi yang telah diberikannya terhadap suatu instansi atau perusahaan. Insentif diberikan guna mendorong produktivitas kerja yang lebih tinggi bagi pegawainya. Insentif yang diberikan telah sesuai dengan yang diharapkan pegawai.

Disiplin kerja dipergunakan para manajer untuk berkomunikasi dengan pegawai agar mereka bersedia untuk mengubah suatu perilaku serta sebagai suatu upaya untuk meningkatkan kesadaran dan kesediaan seorang dalam memenuhi segala peraturan perusahaan. Jika pegawai dapat bekerja secara disiplin, maka akan meningkatkan kinerja pegawai secara keseluruhan.

Kinerja merupakan aspek penting dalam upaya pencapaian tujuan. Unsur yang terpenting dalam pencapaian kinerja ini adalah pegawai. Pegawai adalah manusia atau orang yang melaksanakan suatu pekerjaan pada suatu organisasi baik pemerintah maupun swasta, dan karena jasa dan pekerjaannya itu memperoleh upah atau gaji. Pegawai yang memiliki kinerja yang baik, tentu lebih diharapkan pencapaian tujuannya berhasil, dibanding pegawai yang kinerjanya buruk.

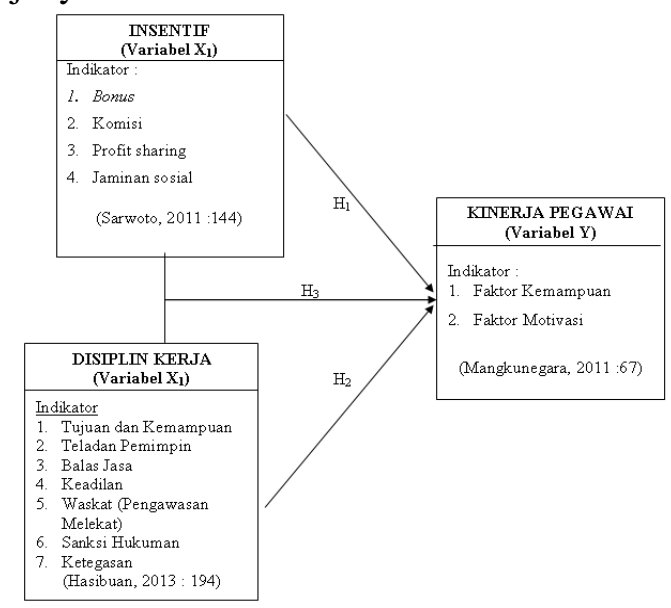

Hipotesis yang penulis ajukan adalah sebagai berikut:

1. Hipotesis I Diduga terdapat pengaruh signifikan insentif terhadap kinerja pegawai pada Kecamatan Citangkil Kota Cilegon

2. Hipotesis II Diduga terdapat pengaruh signifikan disiplin kerja terhadap kinerja pegawai pada Kecamatan Citangkil Kota Cilegon

3. Hipotesis III Diduga terdapat pengaruh yang signifikan insentif dan disiplin kerja terhadap kinerja pegawai pada Kecamatan Citangkil Kota Cilegon

\section{METODE PENELITIAN}

Menurut Sugiyono (2014 : 14) penelitian ini penulis mempergunakan metode penelitian kuantitatif. Metode penelitian kuantitatif dapat diartikan sebagai metode penelitian yang berdasarkan pada filsafat positivisme, digunakan untuk meneliti pada populasi atau sampel tertentu, teknik pengambilan sampel pada umumnya dilakukan secara random, pengumpulan data menggunakan instrumen penelitian, analisis data bersifat kuantitatif/statistik dengan tujuan untuk menguji hipotesis yang ditetapkan. 
Hipotesis dalam penelitian ini penulis menggunakan deskriptif asosiatif. Hipotesis deskriptif adalah jawaban sementara terhadap masalah deskriptif, yaitu yang berkenaan dengan variabel mandiri, sedangkan hipotesis asosiatif adalah jawaban sementara terhadap rumusan masalah, yaitu menanyakan hubungan dua variabel atau lebih. Adapun yang menjadi populasi dalam penelitian ini adalah pegawai Kecamatan Citangkil Kota Cilegon jumlah pegawai yang dijadikan objek penelitian pada Pegawai Negeri Sipil (PNS) sebanyak 67 orang dan pegawai Non PNS sebanyak 35 orang. Jumlah populasi dalam penelitian ini sebanyak 102 orang / pegawai. Sampel ditetapkan sebanyak 31 responden.

\section{HASIL DAN PEMBAHASAN}

\section{Uji Hipotesis}

Uji Hipotesis 1 Pengaruh Insentif $\left(\mathrm{X}_{1}\right)$ terhadap Kinerja Pegawai (Y) pada Kecamatan Citangkil Kota Cilegon

Untuk menguji signifikansi apakah hipotesis yang ditetapkan semula diterima atau ditolak, dengan cara membandingkan antara $t_{\text {hitung }}$ dengan $t_{\text {tabel. }}$. Hasil yang didapatkan dari SPSS Versi 21 memberikan thitung untuk variabel Motivasi pada tabel dibawah ini.

Tabel 1 Uji t

Variabel Insentif (X1) terhadap Kinerja Pegawai (Y)

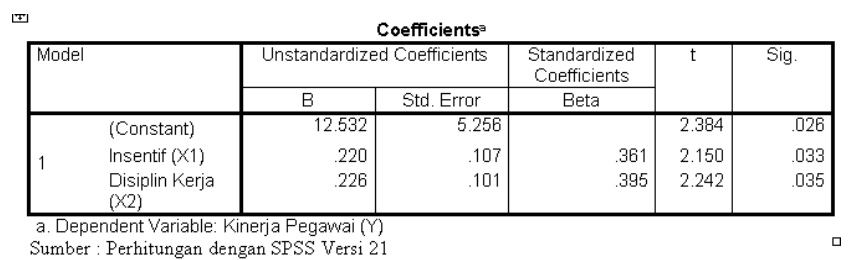

Berdasarkan hasil output di atas, maka dapat diketahui apakah sebenarnya motivasi mempunyai pengaruh terhadap kinerja pegawai, dan hasil perhitungan yang didapat adalah dk n-2 $(31-2=29)$ maka diperoleh $t_{\text {tabel }}$ sebesar 2,045 sedangkan $t_{\text {hitung }}$ sebesar 2,150 maka Insentif $\left(\mathrm{X}_{1}\right)$ terhadap kinerja pegawai (Y) dalam uji $t$, didapat hasil $t_{\text {hitung }}>t_{\text {tabel }}$ $(2,150>2,069)$ dengan tingkat signifikansi sebesar $0,03(0,03<0,05)$ maka dapat disimpulkan bahwa terdapat pengaruh yang signifikan antara disiplin kerja terhadap kinerja pegawai pada Kecamatan Citangkil Kota Cilegon.

a. Uji Hipotesis 2 Pengaruh Disiplin Kerja $\left(\mathrm{X}_{2}\right)$ terhadap Kinerja Pegawai (Y) pada Kecamatan Citangkil Kota Cilegon
Untuk menguji signifikansi apakah hipotesis yang ditetapkan semula diterima atau ditolak, dengan cara membandingkan antara $t_{\text {hitung }}$ dengan $t_{\text {tabel. }}$. Hasil yang didapatkan dari SPSS Versi 21 memberikan thitung untuk variabel disiplin kerja $\left(\mathrm{X}_{2}\right)$ dan kinerja pegawai (Y) pada tabel dibawah ini.

\section{Tabel 2 Uji t}

Variabel Disiplin kerja $\left(\mathrm{X}_{2}\right)$ terhadap Kinerja pegawai (Y)

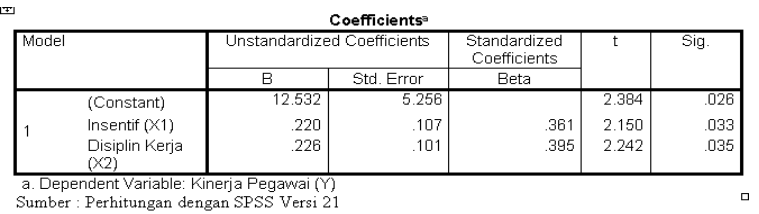

Berdasarkan hasil output di atas, maka dapat diketahui apakah sebenarnya disiplin kerja mempunyai pengaruh terhadap kinerja pegawai, dan hasil perhitungan yang didapat adalah dk n-2 (31-2=29) maka diperoleh $t_{\text {tabel }}$ sebesar 2,045 sedangkan $t_{\text {hitung }}$ 2,242 maka disiplin kerja $\left(\mathrm{X}_{2}\right)$ terhadap kinerja pegawai (Y) dalam uji $t$, didapat hasil $t_{\text {hitung }}>t_{\text {tabel }}$ $(4,106>2,069)$ dengan tingkat signifikansi sebesar $0,03(0,03<0,05)$ maka dapat disimpulkan bahwa terdapat pengaruh yang signifikan antara disiplin kerja terhadap kinerja pegawai pada Kecamatan Citangkil Kota Cilegon.

Uji Hipotesis 3 Insentif $\left(X_{1}\right)$ dan Disiplin Kerja $\left(X_{2}\right)$ secara simultan mempunyai pengaruh terhadap Kinerja Pegawai (Y)

Dalam uji $F$ untuk membuktikan apakah variabel Insentif $\left(\mathrm{X}_{1}\right)$ dan disiplin kerja $\left(\mathrm{X}_{2}\right)$ secara simultan mempunyai pengaruh terhadap kinerja pegawai (Y), maka dilakukan uji $\mathrm{F}$

\begin{tabular}{|c|c|c|c|c|c|c|}
\hline \multicolumn{2}{|c|}{ Model } & $\begin{array}{c}\text { Sum of } \\
\text { Squares }\end{array}$ & $\mathrm{df}$ & $\begin{array}{c}\text { Mean } \\
\text { Square }\end{array}$ & $\bar{F}$ & Sig. \\
\hline \multirow{3}{*}{1} & Regression & 54.113 & 2 & 27.056 & 6.096 & $.008^{b}$ \\
\hline & Residual & 97.647 & 22 & 4.439 & & \\
\hline & Total & 151.760 & 24 & & & \\
\hline
\end{tabular}

Setelah pengujian dilakukan diperoleh $\mathrm{F}_{\text {hitung }}=$ 6,096 sedangkan nilai $\mathrm{F}_{\text {tabel }}(\mathrm{df}=\mathrm{n}-\mathrm{k}-1=31-2-1=28)$ sebesar 3,440 dengan taraf nyata sebesar $0,05 . \mathrm{F}_{\text {hitung }}>$ $\mathrm{F}_{\text {tabel }}(6,096>3,443)$ dengan tingkat signifikansi sebesar $0,008(0,008<0,05)$ maka dapat disimpulkan 
bahwa terdapat pengaruh yang signifikan antara disiplin dan disiplin kerja terhadap kinerja pegawai pada Kecamatan Citangkil Kota Cilegon.

\section{Pembahasan Hasil Penelitian}

Terdapat pengaruh yang signifikan antara insentif terhadap kinerja pegawai pada Kecamatan Citangkil Kota Cilegon dalam uji t, didapat hasil thitung $>t_{\text {tabel }}(2,150>2,069)$ dengan tingkat signifikansi sebesar $0,03(0,03<0,05)$ maka dapat disimpulkan bahwa terdapat pengaruh yang signifikan antara insentif terhadap kinerja pegawai pada Kecamatan Citangkil Kota Cilegon sedangkan nilai korelasi sebesar 0,400 artinya nilai insentif semakin meningkat maka kinerja akan semakin meningkat.

Hasil penelitian ini sesuai dengan penelitian Serliana, M.Z, dkk (2018) dan Normi (2015) yang menyatakan penelitiannya insentif berpengaruh positif terhadap kinerja. Hasil analisis tersebut bermakna semakin tinggi insentif maka semakin meningkat pula kinerja. Dengan demikian hipotesis tentang adanya pengaruh insentif terhadap kinerja pegawai.

Terdapat pengaruh yang signifikan antara disiplin kerja terhadap kinerja pegawai pada Kecamatan Citangkil Kota Cilegon dalam uji t, didapat hasil $t_{\text {hitung }}>t_{\text {tabel }}(2,242>2,069)$ dengan tingkat signifikansi sebesar $0,03(0,03<0,05)$ maka dapat disimpulkan bahwa terdapat pengaruh yang signifikan antara disiplin kerja terhadap kinerja pegawai pada Kecamatan Citangkil Kota Cilegon sedangkan nilai korelasi sebesar 0,431 artinya nilai disiplin kerja semakin meningkat maka disiplin kerja akan semakin meningkat.

Hasil penelitian ini sesuai dengan penelitian Septiasari dan Dayang (2017) serta Pangarso dan Intan (2016) yang menyatakan hasil penelitiannya bahwa disiplin kerja berpengaruh positif signifikan terhadap kinerja pegawai. Dari penjelasan tersebut dapat disimpulkan bahwa adanya disiplin kerja yang baik maka akan menghasilkan kinerja pegawai yang baik, sebaliknya apabila disiplin kerja kurang baik akan menghasilkan kinerja pegawai yang kurang baik pula

Pengujian secara simultan diperoleh $\mathrm{F}_{\text {hitung }}>$ $F_{\text {tabel }}(6,096>3,443)$ dengan tingkat signifikansi sebesar 0,008 $(0,008<0,05)$ maka dapat disimpulkan bahwa terdapat pengaruh yang signifikan antara disiplin dan disiplin kerja terhadap kinerja pegawai pada Kecamatan Citangkil Kota Cilegon.
Hasil penelitian ini sesuai dengan penelitian Handoko dan Waluyo (2017) hasil pengujian secara bersamaan (simultan) menyatakan adanya pengaruh antara variabel disiplin kerja dan pemberian insentif terhadap kinerja karyawan. Hal itu dibuktikan semakin tinggi frekuensi disiplin kerja dilaksanakan dan semakin baik atau semakin tinggi pemberian insentif di dalam sebuah perusahaan akan berdampak semakin tingginya kinerja karyawan dengan demikian dapat disimpulkan terdapat pengaruh signifikan antara disiplin kerja dan pemberian insentif terhadap kinerja karyawan.

\section{KESIMPULAN DAN SARAN}

Berdasarkan hasil analisis dan pembahasan disiplin dan disiplin kerja terhadap kinerja pegawai pada Kecamatan Citangkil Kota Cilegon, penulis menarik kesimpulan bahwa pengaruh insentif terhadap kinerja pegawai pada Kecamatan Citangkil Kota Cilegon diperoleh thitung > ttabel $(2,150>2,069)$ dengan tingkat signifikansi sebesar $0,03(0,03<0,05)$ maka dapat disimpulkan bahwa terdapat pengaruh yang signifikan antara insentif terhadap kinerja pegawai pada Kecamatan Citangkil Kota Cilegon sedangkan nilai korelasi sebesar 0,400 artinya nilai insentif semakin meningkat maka kinerja akan semakin meningkat. Pengaruh disiplin kerja terhadap kinerja pegawai pada Kecamatan Citangkil Kota Cilegon didapat hasil thitung > ttabel $(2,242>2,069)$ dengan tingkat signifikansi sebesar 0,03 $(0,03<0,05)$ maka dapat disimpulkan bahwa terdapat pengaruh yang signifikan antara disiplin kerja terhadap kinerja pegawai pada Kecamatan Citangkil Kota Cilegon sedangkan nilai korelasi sebesar 0,431 artinya nilai disiplin kerja semakin meningkat maka disiplin kerja akan semakin meningkat. Pengaruh disiplin dan disiplin kerja terhadap kinerja pegawai pada Kecamatan Citangkil Kota Cilegon dengan pengujian secara simultan diperoleh Fhitung > Ftabel (6,096 > 3,443) dengan tingkat signifikansi sebesar 0,008 $(0,008<0,05)$ maka dapat disimpulkan bahwa terdapat pengaruh yang signifikan antara disiplin dan disiplin kerja terhadap kinerja pegawai pada Kecamatan Citangkil Kota Cilegon.

\section{REFERENSI}

[1] Keegan, W. (2003). Manajemen Pemasaran Global, Jakarta : PT. Gramedia Pustaka Utama 
[2] Tanton,W. J. (2002). Prinsip Pemasaran, Edisi 7, Alih Bahasa : Y. Lamarto dan Sadu Sundaya. Jakarta : Erlangga.

[3] Winarno, F.G (1992). Kimia Pangan dan Gizi . Jakarta : PT. Gramedia Pustaka Utama.

[4] Repository. "Target dan luaran" https://repository.unej.ac.id/bitstream/handle/123 456789/57911/7.Target\%20dan\%20Luaran.pdf?s equence $=7$ (diakses 12 juni 2019)

[5] Ubpkarawang. "analisis produk pemasaran produk umkm dodol garut" http://journal.ubpkarawang.ac.id/index.php/Manaj emen/article/view/164 (diakses 12 juni 2019)

[6] Repository. "studi deskriptif tentang pengembangan usaha dodol garut"
http://repository.upi.edu/27061/4/S_PEK_120386 8_Chapter\%201.pdf (diakses 13 juni 2019)

[7] Roro diyah. "20 manfaat pada tepung garut" https://manfaat.co.id/manfaat-tepung-garut (diakses 17 juni 2019)

[8] Wikipedia. "Uji Organoleptik" https://id.wikipedia.org/wiki/Uji_organoleptik (diakses 17 Juni 2019)

[9] Repository. "PRODUKTIVITAS TALAS (Colocasia esculenta L. Shott) DI BAWAH TIGA JENIS TEGAKAN DENGAN SISTEM AGROFORESTRI DI LAHAN HUTAN RAKYAT", https://repository.ipb.ac.id/jspui/bitstream/123456 789/61934/2/BAB\%20II\%20Tinjauan\%20Pustak a.pdf (diakses 5 juli 2019) 